\title{
Antioxidant Enzyme Inhibitor Role of Phosphine Metal Complexes in Lung and Leukemia Cell Lines
}

\author{
Burcu Saygıdeğer Demir, ${ }^{1}$ Tuğba Keleş, ${ }^{2}$ and Osman Serindağ $\breve{g}^{3}$ \\ ${ }^{1}$ Department of Chemistry, Science, and Letters Faculty, Osmaniye Korkut Ata University, Fakıuşağı, 80000 Osmaniye, Turkey \\ ${ }^{2}$ Department of Chemistry and Chemical Technology, University of Bayburt, 69000 Bayburt, Turkey \\ ${ }^{3}$ Science Institute, Kanuni University, 01170 Adana, Turkey \\ Correspondence should be addressed to Burcu Saygıdeğer Demir; burcudemir@osmaniye.edu.tr
}

Received 2 May 2014; Accepted 1 December 2014; Published 28 December 2014

Academic Editor: Claudio Pettinari

Copyright (c) 2014 Burcu Saygıdeğer Demir et al. This is an open access article distributed under the Creative Commons Attribution License, which permits unrestricted use, distribution, and reproduction in any medium, provided the original work is properly cited.

\begin{abstract}
Phosphine metal complexes have been recently evaluated in the field of cancer therapy. In this research, the cytotoxic effects of some metal phosphines $\left\{\left[\mathrm{PdCl}_{2}\left(\left(\mathrm{CH}_{2} \mathrm{OH}\right)_{2} \mathrm{PCH}_{2}\right)_{2} \mathrm{NCH}_{3}\right](\mathrm{Cl}), \quad\left[\mathrm{RuCl}_{2}\left(\left(\left(\mathrm{CH}_{2} \mathrm{OH}\right)_{2} \mathrm{PCH}_{2}\right)_{2} \mathrm{NCH}_{3}\right)_{2}\right]\left(\mathrm{C}_{2}\right)\right.$, $\left.\left[\mathrm{PtCl}_{2}\left(\left(\mathrm{Ph}_{2} \mathrm{PCH}_{2}\right)_{2} \mathrm{NCH}_{3}\right)(\mathrm{timin})_{2}\right](\mathrm{C} 3)\right\}$ on $\mathrm{K} 562$ (human myelogenous leukemia cell line) and A549 (adenocarcinomic human alveolar basal epithelial cells) cells were investigated using the MTT test. C1 and C2 are water-soluble metal complexes, which may have some advantages in in vitro and in vivo studies. The effects of the above-mentioned metal complexes on thioredoxin reductase (TrxR) (EC: 1.8.1.9), glutathione peroxidase (GPx) (EC: 1.11.1.9), and catalase (Cat) (EC: 1.11.1.6) enzymes were also tested. The results of this research showed that all three metal complexes indicated dose-dependent cytotoxicity on A549 and K562 cell lines and that the complexes inhibited different percentages of the TrxR, GPx, and Cat enzymes of these tumor cells.
\end{abstract}

\section{Introduction}

Some anticancer agents act through production of ROS (reactive oxygen species) to kill tumor cells. Reported studies have shown that cells with high levels of antioxidant enzymes are resistant to some anticancer agents $[1,2]$. The inhibition of these enzymes is an indicator of apoptotic pathways, and organometallic compounds have been most recently used as the first step of cancer drug discovery [3-5].

In the last three decades, metal complexes have been of interest to cancer therapy researchers. The international community has widely recognized that while some ruthenium complexes exhibit low toxicity to normal cells, they are easily absorbed by tumor tissue and rapidly excreted from the body [3-7], and ruthenium complexes bearing promising anticancer activity have successfully entered into clinical trials [3, $8-10]$. In addition to ruthenium complexes, the investigation of platinum and palladium complexes is also important for the treatment of some human cancers [11]. Many of the properties that make metal-phosphine complexes attractive for use in catalysis are also relevant for medicinal applications such as anti-inflammatory, antibacterial, and antitumoral studies. The earliest example of an antitumoral application of a metal-phosphine complex is the gold(I) complex auranofin [12]. Several phosphine metal complexes have been synthesized to treat cancer cells after the discovery of auranofin [13$16]$.

Antioxidant enzymes in cancer cells, such as GPx, GR, and especially TrxR, are major targets for recent antitumor drug studies. Several different clinical antitumor agents have been reported to inactivate TrxR. However, the relationship between TrxR inactivation and apoptosis has been less fully reported [17]. In normal cells, TrxR1 is necessary for redox homeostasis and protection against oxidative damage and mutation. Once transformation into a malignant cell has taken place, TrxR1 supports tumor growth and progression. In recent years, strong connections have been identified between the thioredoxin system and the apoptosis regulator protein $\mathrm{p} 53$ [5]. One of the reasons for preferring TrxR as a molecular target is the fact that it is a selenoprotein containing a selenocysteine on the flexible C-terminal arm of its active site (-Gly-Cys-SeCys-Gly-) which is very accessible 
during catalysis. Many electrophilic compounds selectively and irreversibly modify the active site amino acids of TrxR [18-22]. Since GPx has cysteine and selenocysteine residue in its active site, the inactivation mechanism of GPx with metal complexes resembles that of TrxR [23]. Inactivation of Cat having histidine, aspartic acid, and phenyl alanine amino acids in its active site might be carried out via coordination of these amino acids to metal complexes or coordination of other amino acids outside the catalytic site [24].

The cytotoxic activities of $\mathrm{Ru}(\mathrm{II}), \mathrm{Pd}(\mathrm{II})$, and $\mathrm{Pt}(\mathrm{II})$ phosphine complexes on A549 and K562 cell lines, and the inactivation of the GPx, Cat, and TrxR enzymes of these cells via the metal phosphine complexes have been investigated in this study.

\section{Material and Method}

2.1. Synthesis. All reactions were carried out under purified nitrogen using standard Schlenk techniques. Solvents were purified by standard methods and distilled under nitrogen prior to use. $\left[\mathrm{PdCl}_{2}\left(\left(\mathrm{CH}_{2} \mathrm{OH}\right)_{2} \mathrm{PCH}_{2}\right)_{2} \mathrm{NCH}_{3}\right](\mathrm{Cl})$, $\left.\left[\mathrm{PtCl}_{2}\left(\left(\mathrm{Ph}_{2} \mathrm{PCH}_{2}\right)_{2} \mathrm{NCH}_{3}\right) \text { (timin }\right)_{2}\right]$ (C3) was prepared according to the procedure described in the literature [25, 26]. $\left[\mathrm{RuCl}_{2}\left(\left(\left(\mathrm{CH}_{2} \mathrm{OH}\right)_{2} \mathrm{PCH}_{2}\right)_{2} \mathrm{NCH}_{3}\right)_{2}\right]$ was synthesized according to the new method for this study. NMR spectra were recorded on a Bruker ARX-300 spectrometer using $\mathrm{D}_{2} \mathrm{O}$ and $\mathrm{CDCl}_{3}$ as solvents. In the NMR spectra, the ${ }^{1} \mathrm{H}$ and ${ }^{13} \mathrm{C}$ chemical shifts are reported in ppm, downfield from the internal standard $\mathrm{SiMe}_{4}$. The ${ }^{31} \mathrm{P}$ NMR $(121.5 \mathrm{MHz})$ spectra were recorded with $85 \% \mathrm{H}_{3} \mathrm{PO}_{4}$ as an external standard, and positive chemical shifts lie downfield of the standard. Elemental analyses were performed by the Inonu University Research Laboratory in Malatya, Turkey. All reagents were purchased from Aldrich Chemical Co. and were used without further purification.

2.1.1. Synthesis of $\left[\mathrm{RuCl}_{2}\left(\left(\left(\mathrm{CH}_{2} \mathrm{OH}\right)_{2} \mathrm{PCH}_{2}\right)_{2} \mathrm{NCH}_{3}\right)_{2}\right]$ (C2). An aqueous solution $(10 \mathrm{~mL})$ of $\left[\left(\left(\mathrm{CH}_{2} \mathrm{OH}\right)_{2} \mathrm{PCH}_{2}\right)_{2} \mathrm{NCH}_{3}\right]$ $(2 \mathrm{mmol})$ was added dropwise to the ruthenium precursor $\left[\mathrm{Ru}(\mathrm{COD}) \mathrm{Cl}_{2}\right](0.95 \mathrm{mmol})$ in toluene $(10 \mathrm{~mL})$ at $40^{\circ} \mathrm{C}$ with constant stirring. The mixture was further stirred for $48 \mathrm{~h}$, and the aqueous layer was separated from the organic layer. The aqueous solution was concentrated to $5 \mathrm{~mL}$ in vacuum and evaporated slowly at room temperature to afford the green colored complex $\mathrm{C} 2$ at $78 \%$ yield.

Anal. Calcd. for $\left[\mathrm{RuCl}_{2}\left(\left(\left(\mathrm{CH}_{2} \mathrm{OH}\right)_{2} \mathrm{PCH}_{2}\right)_{2} \mathrm{NCH}_{3}\right)_{2}\right]$ (C2): C, 25.6\%; H, 5.8\%; N, 4.3\%. Found: C, 27.1\%; H, 6.5\%; N, 4.09\%. $\left\{{ }^{1} \mathrm{H}\right\} \mathrm{NMR}\left(\mathrm{D}_{2} \mathrm{O}, 25^{\circ} \mathrm{C}\right): \delta 3.6\left(\mathrm{~s}, 16 \mathrm{H}, \mathrm{PCH}_{2} \mathrm{OH}\right), \delta 3.2$ $\left(\mathrm{s}, 8 \mathrm{H}, \mathrm{PCH}_{2} \mathrm{~N}\right), \delta 2.5\left(\mathrm{~s}, 6 \mathrm{H}, \mathrm{NCH}_{3}\right) .\left\{{ }^{31} \mathrm{P}-\left[{ }^{1} \mathrm{H}\right]\right\} \mathrm{NMR}\left(\mathrm{D}_{2} \mathrm{O}\right.$, $\left.25^{\circ} \mathrm{C}\right): \delta 6.5 \mathrm{ppm}(\mathrm{s}, \mathrm{Ru}-\mathrm{P}),\left\{{ }^{13} \mathrm{C}\right\} \mathrm{NMR}\left(\mathrm{d}-\mathrm{DMSO}, 25^{\circ} \mathrm{C}\right): \delta$ $59 \mathrm{ppm}\left(\mathrm{s},-\mathrm{PCH}_{2} \mathrm{OH}\right), \delta 47 \mathrm{ppm}\left(\mathrm{m},-\mathrm{NCH}_{3}\right), \delta 24.5(\mathrm{~s}$, $\left.\mathrm{PCH}_{2} \mathrm{~N}\right)$ FT-IR $\left(\mathrm{KBr}, \mathrm{cm}^{-1}\right) 1250(\mathrm{C}-\mathrm{OH}), 1050(\mathrm{~N}-\mathrm{C}), 1460$ (C-H), 1150 (P-C-N(R)-C-P) 3200-3400 (O-H).

2.2. Cell Culture. In order to examine the anticancer activities of metal phosphine complexes, two different human cancer cell lines were used: a K562 cell line provided by Cukurova University's Hematology Clinic and an A549 cell line supplied by Gaziantep University's Cell Culture Laboratory. The cancer cells were maintained in the logarithmic phase at $37^{\circ} \mathrm{C}$ in a $5 \%$ carbon dioxide atmosphere using a culture medium containing $10 \%$ fetal bovine serum, $1 \%$ penicillin, and $1 \%$ streptomycin RPMI-1640 (Sigma) (developed by Roswell Park Memorial Institute).

2.3. MTT Test (Cytotoxicity Test). The growth inhibitory effect towards cancer cell lines was evaluated by means of MTT (3-(4,5-dimethylthiazol-2-yl)-2,5-diphenyltetrazolium bromide, a yellow tetrazole) assay [27]. Briefly, $3 \times 10^{3}$ cells/ well, dependent upon the growth characteristics of the cell line, were seeded in 96-well microplates in the growth medium $(100 \mu \mathrm{L})$ and then incubated at $37^{\circ} \mathrm{C}$ in a $5 \%$ carbon dioxide atmosphere. After $24 \mathrm{~h}$, the medium was removed and replaced with a fresh medium containing the appropriate concentrations $(47.62,38.01,28.57,19.05,9.52$, and 4.76 $\mathrm{iu} \cdot \mathrm{mL}^{-1}$ ) of the phosphine metal complexes being studied. Triplicate cultures were established for each treatment. After $48 \mathrm{~h}$, each well was treated with $10 \mu \mathrm{L}$ of a $5 \mathrm{mg} \cdot \mathrm{mL}^{-1}$ MTT saline solution, and following $5 \mathrm{~h}$ of incubation, $100 \mu \mathrm{L}$ of dimethyl sulfoxide (DMSO) was added. The inhibition of cell growth induced by the phosphine metal complexes was detected after incubation (30 minutes) by measuring the absorbance of each well at $570 \mathrm{~nm}$ using a Bio-Rad 680 microplate reader. The $\mathrm{IC}_{50}$ values represent the concentrations of phosphine metal complexes that reduce the mean absorbance at $570 \mathrm{~nm}$ to $50 \%$ of those in the untreated control wells containing only culture medium. Thus, cytotoxicities of the compounds were determined. All data were from at least three independent experiments and are expressed as mean \pm standard deviation.

2.4. Catalase Activity Assay. Catalase activity was measured as described by Claiborne [28]. $3 \times 10^{3}$ cells/well were plated in 96 -well microplates in a growth medium $(100 \mu \mathrm{L})$ and then incubated at $37^{\circ} \mathrm{C}$ in a $5 \%$ carbon dioxide atmosphere. After $24 \mathrm{~h}$, the medium was removed and replaced with a fresh one containing the $\mathrm{IC}_{50}$ values of the metal complexes for each cell for $48 \mathrm{~h}$. The cells were washed twice in a phosphate buffer solution (PBS) and then collected; a protease inhibitor cocktail purchased from Sigma was added into the cell suspension and sonicated in a $50 \mathrm{mM}$ potassium phosphate buffer $(\mathrm{PB}$, $\mathrm{pH}$ 7.0) on ice for $25 \mathrm{~s}$ (using Bandelin SONOPULS HD 2200 ultrasonic homogenizer) at a $10 \%$ output and $80 \%$ duty cycle. After the sonication procedure, the protein concentration was determined by Lowry at al's method for Cat and other enzyme activity assays [29].

Cell extracts (200-400 mg) were added to $3 \mathrm{~mL}$ of a $10 \mathrm{mM} \mathrm{H}_{2} \mathrm{O}_{2}$ in $50 \mathrm{mM}$ potassium phosphate buffer ( $\mathrm{pH} 7.8$ ) and the disappearance of $\mathrm{H}_{2} \mathrm{O}_{2}$ (extinction coefficient $(\varepsilon)$ of $0.0396 \mathrm{~cm}^{2} \cdot \mu \mathrm{mol}^{-1}$ ) was immediately measured at $240 \mathrm{~nm}$ for $60 \mathrm{~s}$ at $15 \mathrm{~s}$ intervals. Catalase activity was expressed in units per grams of protein.

2.5. Glutathione Peroxidase Activity Assay. After applying the same sonicating procedure to the cells, each $5 \mu \mathrm{L}$ sample of the cell content was incubated for $10 \mathrm{~min}$ at $37^{\circ} \mathrm{C}$ in a $495 \mu \mathrm{L}$ 
TABLE 1: Specific activities of TrxR, GPx, and Cat enzymes in the given period, after incubation of A549 and K562 cells, with IC ${ }_{50}$ values of metal complexes.

\begin{tabular}{|c|c|c|c|c|c|}
\hline \multicolumn{3}{|c|}{ A549 } & \multicolumn{3}{|c|}{ K562 } \\
\hline & & $\mathrm{U} / \mathrm{mg}$ protein & & & $\mathrm{U} / \mathrm{mg}$ protein \\
\hline \multirow{4}{*}{$\operatorname{Trx} R$} & Control & $0.5080^{\mathrm{ax}} \pm(0.00458)^{\mathrm{y}}$ & \multirow{4}{*}{ TrxR } & Control & $1.0640^{\mathrm{a}} \pm(0.00529)$ \\
\hline & $\mathrm{C} 1$ & $0.4740^{\mathrm{a}} \pm(0.00529)$ & & $\mathrm{C} 1$ & $0.5867^{\mathrm{d}} \pm(0.01155)$ \\
\hline & $\mathrm{C} 2$ & $0.2600^{\mathrm{b}} \pm(0.01114)$ & & $\mathrm{C} 2$ & $0.7200^{\mathrm{b}} \pm(0.05568)$ \\
\hline & $\mathrm{C} 3$ & $0.2960^{\mathrm{b}} \pm(0.00557)$ & & $\mathrm{C} 3$ & $0.6070^{c} \pm(0.02000)$ \\
\hline \multirow{4}{*}{ GPx } & Control & $0.1520^{\mathrm{a}} \pm(0.00265)$ & \multirow{4}{*}{ GPx } & Control & $0.2367^{\mathrm{a}} \pm(0.00577)$ \\
\hline & $\mathrm{C} 1$ & $0.0680^{\mathrm{c}} \pm(0.00854)$ & & $\mathrm{C} 1$ & $0.0200^{\mathrm{b}} \pm(0.00000)$ \\
\hline & $\mathrm{C} 2$ & $0.1067^{\mathrm{b}} \pm(0.00351)$ & & $\mathrm{C} 2$ & $0.0000^{\mathrm{b}} \pm(0.00000)$ \\
\hline & $\mathrm{C} 3$ & $0.0460^{\mathrm{d}} \pm(0.00361)$ & & $\mathrm{C} 3$ & $0.0000^{\mathrm{b}} \pm(0.00000)$ \\
\hline \multirow{4}{*}{ Cat } & Control & $854.73^{\mathrm{a}} \pm(0.00008)$ & \multirow{4}{*}{ Cat } & Control & $354.9300^{\mathrm{a}} \pm(3.27432)$ \\
\hline & $\mathrm{Cl}$ & $281.68^{\mathrm{c}} \pm(0.00005)$ & & $\mathrm{C} 1$ & $131.8900^{\mathrm{b}} \pm(1.47401)$ \\
\hline & $\mathrm{C} 2$ & $530.41^{\mathrm{b}} \pm(0.00002)$ & & $\mathrm{C} 2$ & $121.9100^{c} \pm(1.80602)$ \\
\hline & $\mathrm{C} 3$ & $252.36^{\mathrm{d}} \pm(0.00002)$ & & $\mathrm{C} 3$ & $108.8163^{\mathrm{d}} \pm(2.78970)$ \\
\hline
\end{tabular}

Among groups ${ }^{\mathrm{x}}$ mean value $(n=3),{ }^{\mathrm{y}}$ standard deviation, ${ }^{\mathrm{a}-\mathrm{d}}$ Significant differences $(1: P \leq 0.05 ; 2: P \leq 0.01 ; 3: P \leq 0.001)$ in a row.

incubation mixture containing $50 \mu \mathrm{L}$ of a $100 \mathrm{mM}$ potassium phosphate buffer (pH 7.0), $5 \mu \mathrm{L}$ of $100 \mathrm{mM} \mathrm{GSH}, 10 \mu \mathrm{L}$ of $200 \mathrm{mM}$ EDTA, $5 \mu \mathrm{L}$ of $400 \mathrm{mM}$ sodium azide, $50 \mu \mathrm{L}$ of $2 \mathrm{mM}$ $\mathrm{NADPH}, 320 \mu \mathrm{L}$ distilled water, and $50 \mu \mathrm{L}$ GR $\left(10 \mathrm{u} \cdot \mathrm{mL}^{-1}\right)$. After the $10 \mathrm{~min}$ incubation period, the reaction was initiated by the addition of $5 \mu \mathrm{L}$ of $10 \mathrm{mmol} / \mathrm{L}^{-1}$ of $\mathrm{H}_{2} \mathrm{O}_{2}$. The decrease in the absorbance of the system was measured for $30 \mathrm{~s}$ at $340 \mathrm{~nm}$. A similar mixture excluding GSH was used as a blank sample [30]. A unit of activity (U) was defined as the amount of enzymes that catalyzed the oxidation of one micromole of $\mathrm{NADPH}\left(\varepsilon=6.22 \mathrm{mM}^{-1}\right)$ to $\mathrm{NADP}^{+}$in one minute under these conditions.

2.6. Thioredoxin Reductase Activity Assay. Enzyme activity was determined spectrophotometrically by monitoring the NADPH dependent production of 2-nitro-5-thiobenzoate $\left(\varepsilon=13.600 \mathrm{M}^{-1} \cdot \mathrm{cm}^{-1}\right)$ at $412 \mathrm{~nm}$ and at $37^{\circ} \mathrm{C}$ [31]. The sonication step was achieved using the same sonicating procedure as in the other two enzyme assays. Forty microliters of the sample was added to an assay mixture of $100 \mathrm{mM}$ sodium phosphate $\mathrm{pH}$ 7.4, $2 \mathrm{mM}$ EDTA, and $3 \mathrm{mM}$ DTNB. The reaction was initiated by adding $0.2 \mathrm{mM}$ NADPH. The activities of the enzymes were monitored for $60 \mathrm{~s}$. The reaction was linear throughout the entire the experimental period. A unit of thioredoxin reductase activity was expressed as one micromole of NADPH oxidized to $\mathrm{NADP}^{+}$in 1 min under assay conditions.

2.7. Statistical Analyses. To determine whether the differences between the activities of the enzymes of two different cancer cells were significant depending on the $\mathrm{IC}_{50}$ values of the metal complexes, analysis of variance and then Tukey's test were used [32]. Three replicates were used as comparisons for each experiment. Results were also given as mean values \pm standard errors of the three replicates in Table 1. Differences between data were assumed significant at $(1: P \leq 0.05 ; 2$ : $P \leq 0.01 ; 3: P \leq 0.001)$. All statistical analyses were carried out using SPSS 11.5.

\section{Results and Discussion}

\subsection{Results}

3.1.1. Synthesis and Characterization of Metal Complexes. $\mathrm{N}, \mathrm{N}$-bis (hydroxymethyl phosphinomethyl) aminomethyl $\left[\left(\left(\mathrm{CH}_{2} \mathrm{OH}\right)_{2} \mathrm{PCH}_{2}\right)_{2} \mathrm{NCH}_{3}\right]$ (dppam) was synthesized by using the reported procedure [25]. The water-soluble characteristics of these (hydroxymethyl) phosphines presented the prospect of investigating their coordination chemistry in water or under biphasic conditions. Upon interaction with $\left[\mathrm{Ru}(\mathrm{COD}) \mathrm{Cl}_{2}\right]$ in toluene, dppam in water produced the complex $\left[\mathrm{RuCl}_{2}\left(\left(\left(\mathrm{CH}_{2} \mathrm{OH}\right)_{2} \mathrm{PCH}_{2}\right)_{2} \mathrm{NCH}_{3}\right)_{2}\right]$ at $78 \%$ yield (Figure 2). The chemical constitution of $\mathrm{C} 2$ was confirmed by elemental analysis and ${ }^{1} \mathrm{H},{ }^{13} \mathrm{C},{ }^{31} \mathrm{P}$ NMR, and $\mathrm{FAB}$ mass spectroscopies. FAB mass spectrometry was used to identify the molecular ions for the ligand parent ions at $\left[\mathrm{M}^{+} \mathrm{H}^{+}\right]$and $m / z$ 245.3 [25]. Due to very high molecular weight of $\mathrm{C} 2$, molecular mass spectrum for $\left[\mathrm{RuCl}_{2}\left(\left(\left(\mathrm{CH}_{2} \mathrm{OH}\right)_{2} \mathrm{PCH}_{2}\right)_{2} \mathrm{NCH}_{3}\right)_{2}\right]$ could not be clarified. Analysis of the FT-IR spectrum of the metal complex C2 proves that the $\mathrm{O}-\mathrm{H}$ stretch peaks of phosphine exhibit a band between 3300 and $3400 \mathrm{~cm}^{-1}$. The peak at $1050 \mathrm{~cm}^{-1}$ is assigned to the $\mathrm{N}-\mathrm{C}$ stretch, whereas $1050 \mathrm{~cm}^{-1}$ is assigned to the asymmetric bending plane of $\mathrm{CH}_{3}$. Consequently, when the IR spectra of free ligands and the metal complex were compared, and they were found to be similar [25]. The ${ }^{31}$ PNMR spectrum of $\mathrm{C} 2$ consisted of a single resonance at $6.5 \mathrm{ppm}$, indicating a significant downfield shift compared to the free ligand $(-17.3 \mathrm{ppm})$, upon coordination of the phosphine units to the ruthenium (II) center, which is consistent with the literature [33]. The ${ }^{1} \mathrm{H}$ NMR spectrum of $\mathrm{C} 2$ shows multiplets centered at $3.9 \mathrm{ppm}$ for $\mathrm{P}-\mathrm{CH}_{2}-\mathrm{OH}$ protons, suggesting that there is a slight downfield shift compared to the chemical shift of the free ligand (3.6 ppm), with singlet peaks at $3.2 \mathrm{ppm}$ and $2.5 \mathrm{ppm}$, respectively, for $\mathrm{N}-\mathrm{CH}_{2}-\mathrm{P}$ protons and $\mathrm{N}-\mathrm{CH}_{3}$ protons. The ${ }^{13} \mathrm{C}$ NMR spectrum of $\mathrm{C} 2$ shows the similar peaks ligand at $24.5 \mathrm{ppm}$ for the $\mathrm{P}-\mathrm{CH}_{2}-\mathrm{N}$ carbon peak, $47.5 \mathrm{ppm}$ for the $\mathrm{N}-\mathrm{CH}_{3}$ carbon peak, and $59 \mathrm{ppm}$ for 


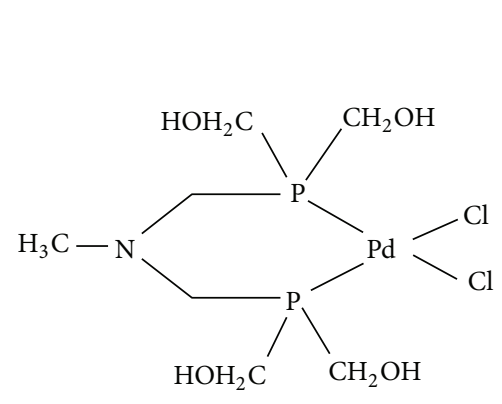

C1

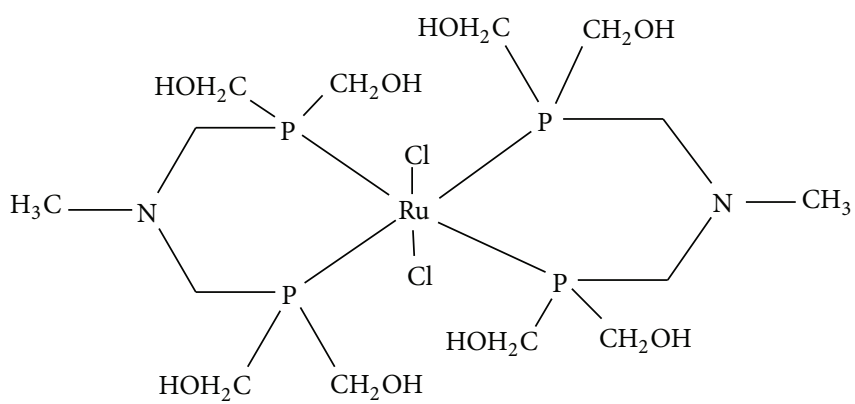

$\mathrm{C} 2$

(a)

(b)

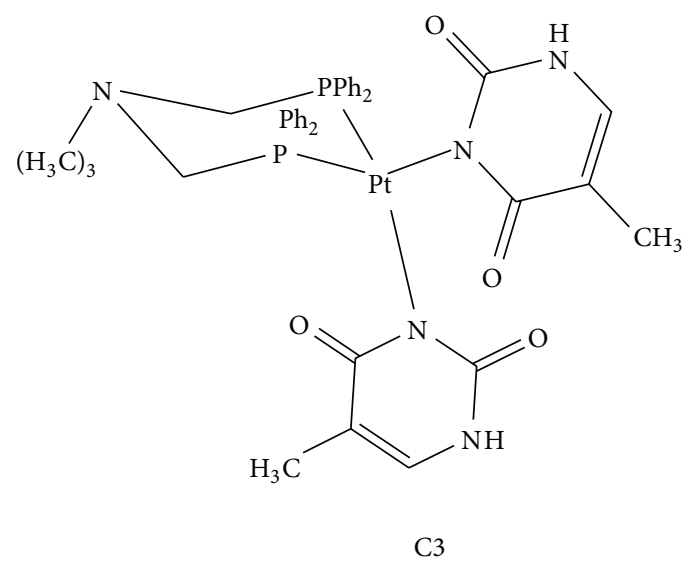

(c)

FIGURE 1: Molecular structures of the phosphine metal complexes used.

$\mathrm{P}-\mathrm{CH}_{2} \mathrm{OH}$. In addition, the literature dates and elemental analysis results show that the complex ratio is $1: 2$ [34].

3.1.2. Cytotoxicity of Metal Complexes. Platin, palladium, and ruthenium complexes of phosphines were used to investigate their cytotoxic activity towards two different cell lines, A549 and K562. Cytotoxicity was evaluated by means of the MTT test after 24, 48, 72, and 120 hours of treatment with increasing concentrations of the aforementioned compounds. The $\mathrm{IC}_{50}$ values which were calculated from dose dependent curves can be seen in Figures 3 and 4. The results showed that A549 cells were resistant to death whereas K562 cells have low resistance in the presence of metal complexes. Considering the resistances of the cell lines, the 120-hour treatment period for K562 cells and the 24-hour treatment period for A549 cells were not studied for cytotoxicity of metal complexes. Among the $24 \mathrm{~h}$ treatment group, only $\mathrm{C} 1$ for K562 had cytotoxic activity, whereas the cell morphology of the others remained relatively unchanged due to its slow penetration of the cells (Figure 5). In the 24-hour treatment of the tested compound, C3 showed better cytotoxic activity for the A549 and K562 cell lines, at $0.158 \mathrm{mM}$ and $0.05 \mathrm{mM}$, respectively. The other tested compounds, $\mathrm{C} 1$ and $\mathrm{C} 2$, showed different cytotoxicities on each cell (C1 on A549: $7.981 \mathrm{mM}, 4.625 \mathrm{mM}$, and $4.575 \mathrm{mM}$ for $48 \mathrm{~h}, 72 \mathrm{~h}$, and $120 \mathrm{~h}$, resp.; $\mathrm{C} 1$ on $\mathrm{K} 562$ : $2.625 \mathrm{mM}$, $3.352 \mathrm{mM}$, and $2.396 \mathrm{mM}$ for $24 \mathrm{~h}, 48 \mathrm{~h}$, and $72 \mathrm{~h}$, resp.; and
C2 on A549: $7.436 \mathrm{mM}$ and $5.302 \mathrm{mM}$ for $72 \mathrm{~h}$ and $120 \mathrm{~h}$, resp.) (Figures 3 and 4). The assignment of microscopic images proved that, after treating with C2, most of the A549 and $\mathrm{K} 562$ cells were still alive after $24 \mathrm{~h}$; likewise, after $48 \mathrm{~h}$, K562 cells treated with $\mathrm{C} 2$ were still alive, based on the microscopic view. So these incubation times were ignored for $\mathrm{C} 1$ and $\mathrm{C} 2$.

3.1.3. Enzyme Studies. Inhibition of the enzymes CAT, TrxR, and GPx by organometallic and other metal compounds in the treatment of cancer has been widely studied. The metal phosphine complexes $\mathrm{C} 1, \mathrm{C} 2$, and $\mathrm{C} 3$ have been studied to examine the inhibition of the above-mentioned enzymes (Figure 1). The general results of the inhibition ratios have been found to be consistent with those of the values in the literature $[15,35]$.

The enzyme activities of the cells incubated with the $\mathrm{IC}_{50}$ values of metal complexes tended to decrease at $72 \mathrm{~h}$ when compared with untreated A549 and K562 cell lines. Table 1 shows a statistically significant decrease in CAT, GPx, and TrxR activities in A549 and K562 cells in the presence of metal complexes.

The TrxR activities of A549 and K562 control cells (untreated with any complex) were found to be $0.508 \mathrm{U} / \mathrm{mg}$ protein and $1.064 \mathrm{U} / \mathrm{mg}$ protein, respectively, and these activities were accepted as $100 \%$ activity. The TrxR activity of 


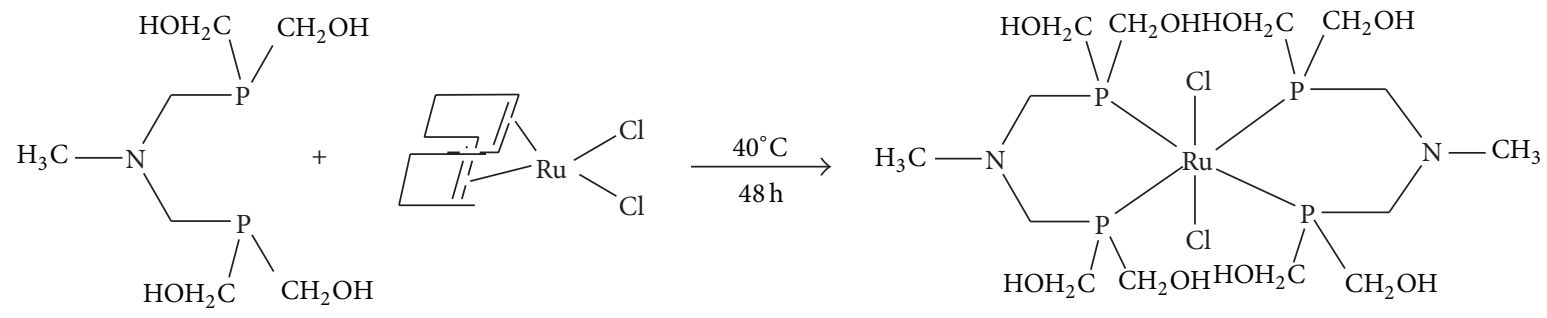

FIgURE 2: Synthesis of $\left[\mathrm{RuCl}_{2}\left(\left(\left(\mathrm{CH}_{2} \mathrm{OH}\right)_{2} \mathrm{PCH}_{2}\right)_{2} \mathrm{NCH}_{3}\right)_{2}\right](\mathrm{C} 2)$ complex.

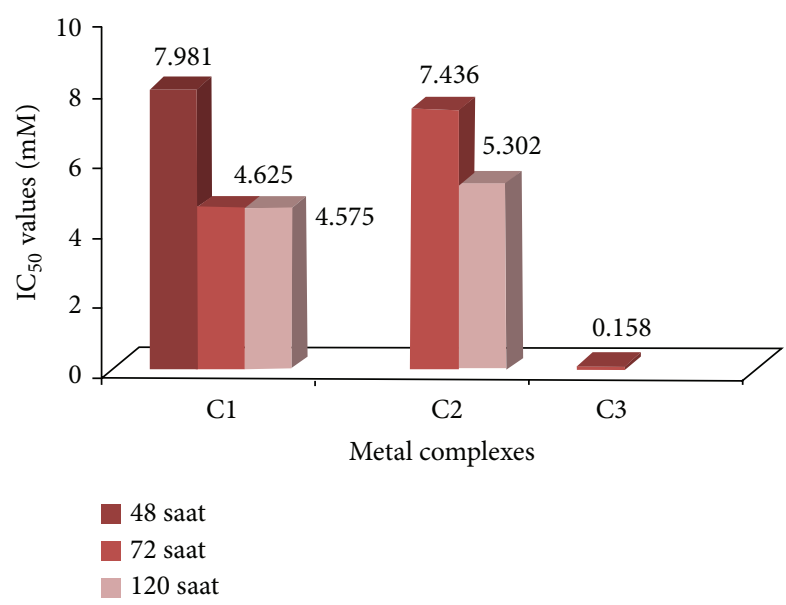

FIGURE 3: IC $_{50}$ values of metal complexes at 48,72 , and $120 \mathrm{~h}$ for A549 cells.

the K562 cells was higher than that of the A549 cells. The TrxR activity of the A549 cells treated with C1 $(4.625 \mathrm{mM}$, $72 \mathrm{~h})$ decreased by $6.69 \%$. The TrxR activity of the A549 cells treated with C3 $(0.158 \mathrm{mM}, 48 \mathrm{~h})$ decreased by $41.73 \%$ (Figure 7). In a reported study, five different ruthenium complexes which had values of $1-100 \mu \mathrm{M} \mathrm{IC}_{50}$ inhibited the TrxR enzyme of A549 cells by $50 \%$ to $100 \%$ [36]. In our study, the inhibition of TrxR in A549 cells with C2 $(7.436 \mathrm{mM}$, $72 \mathrm{~h}$ ) was found to be $48.82 \%$ (Figure 7), which is close to the literature values. As is well known, the complexes of the same ligand with various metals exhibit distinct inhibitions depending on the metal. For instance, the gold complex of hydrophilic alkyl phosphine ligands showed 100\% TrxR inhibition in A549 cells, whereas the silver complex of the same ligand showed 70\% inhibition [13]. The C1 and C2 used in this study demonstrated similar metal-originated results. After incubation of the K562 cells, C1 (2.625 mM, $24 \mathrm{~h})$ and C2 (4.918 mM, $72 \mathrm{~h}$ ) inhibited TrxR by $44.55 \%$ and $32.33 \%$, respectively, compared with the control (Figure 6). The metal complex C3 ( $0.050 \mathrm{mM}, 48 \mathrm{~h}$ ) inhibited the TrxR of K562 cells by $42.96 \%$ (Figure 8 ) and the TrxR of A549 cells by $41.73 \%$ (Figure 7). According to the results of this study, the TrxR enzyme was inhibited via metal complexes, which indicated that cell death may have occurred by an apoptotic pathway. In 2006, Zhao et al. revealed that there was a linear correlation between TrxR activity and cell life, growth, and apoptosis, and they demonstrated the inhibition of TrxR's relationship with

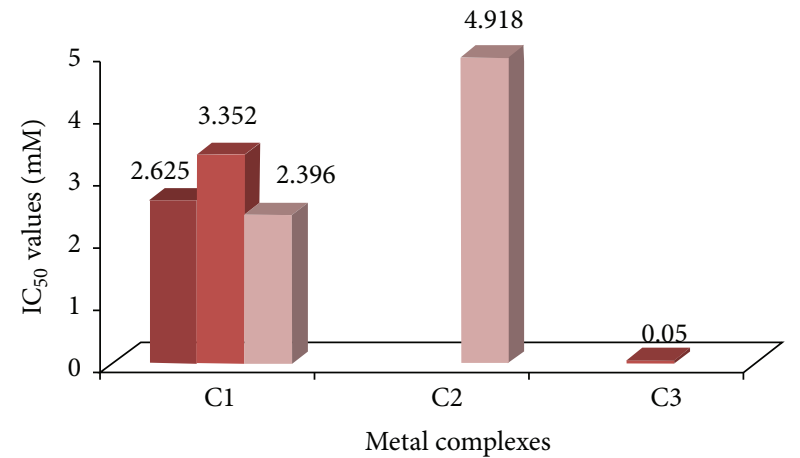

$$
\begin{array}{r}
24 \mathrm{~h} \\
48 \mathrm{~h} \\
72 \mathrm{~h}
\end{array}
$$

FIGURE 4: $\mathrm{IC}_{50}$ values of metal complexes at 24,48 , and $72 \mathrm{~h}$ for $\mathrm{K} 562$ cells.

apoptosis [17]. Although C2 inhibited the TrxR of K562 a little bit more than it did that of A549, it actually showed good inhibition for both types of cells ( 50\%). Witte et al., in 2005, defended the theory that some well-known anticancer agents such as Platinol, Oxaliplatin, and MHC have good inhibitor effects against $\operatorname{TrxR}(50-60 \%)$ [37].

The GPx activity of A549 cells as the control group was found to be $0.152 \mathrm{U} / \mathrm{mg}$ protein. After incubation of the A549 cells with $\mathrm{C} 1$ (4.625 mM, $72 \mathrm{~h}), \mathrm{C} 2$ (7.436 mM, $72 \mathrm{~h})$, and C3 $(0.158 \mathrm{mM} 48 \mathrm{~h})$, their specific activities were calculated as $0.068 \mathrm{U} / \mathrm{mg}, 0.107 \mathrm{U} / \mathrm{mg}$, and $0.046 \mathrm{U} / \mathrm{mg}$ protein, respectively. C3 had the most effective inhibition (69.74\%). $\mathrm{C} 1$ reduced the TrxR enzyme activity in A549 cells by $55.26 \%$, and $\mathrm{C} 2$ reduced it by $29.62 \%$ (Figure 7 ).

A metal complex has different effects on the same enzymes in two different cells, which indicates that metal complexes are cell selective. In a study with gold phosphine complexes concerning cell selectivity, most of the complexes showed good inhibitory effects (more than $80 \%$ ) on the TrxR of A549 cells, but percentages were different in the other tested cell lines. In the same study, it was observed that enzymes were inhibited disparately by the metal complexes. While a gold complex inhibited TrxR by more than $80 \%$, it inhibited both GPx and GR (glutathione reductase) enzymes of the same cell (A549) by under 50\% [4]. C1 caused a $91.67 \%$ decrease in the GPx activity of K562, while C2 and C3 inhibited it completely (Figure 8). 


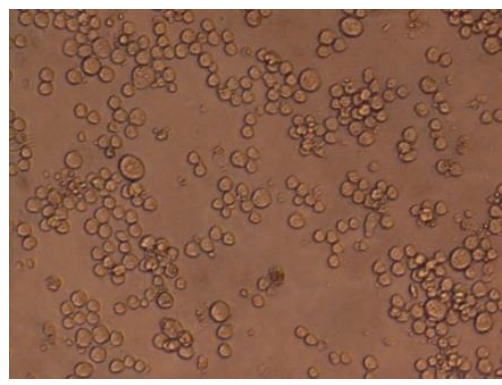

$\mathrm{H}_{2} \mathrm{O} 72 \mathrm{~h}$

(a)

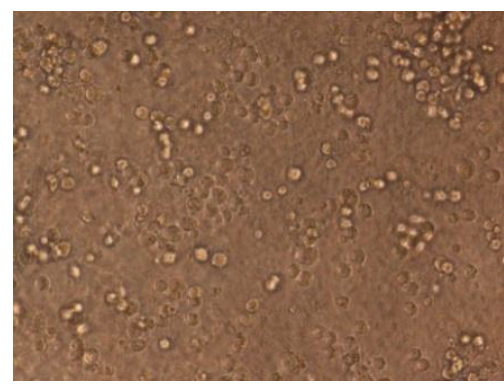

C1 72 h

(b)

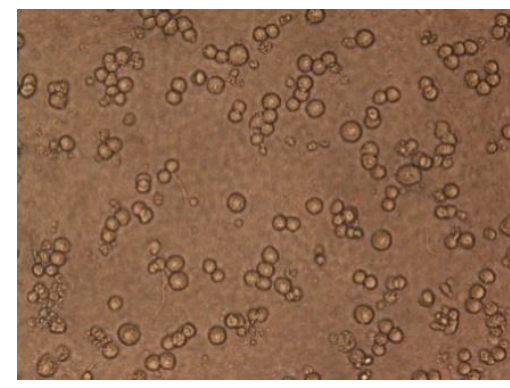

$\mathrm{C} 272 \mathrm{~h}$

(c)

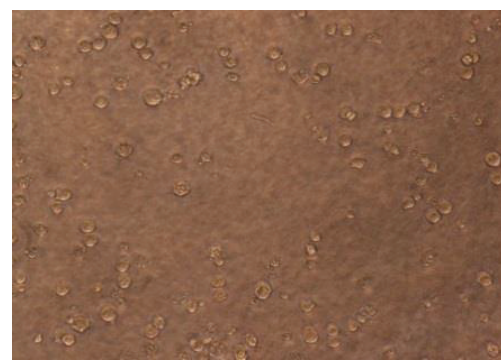

DMSO $48 \mathrm{~h}$

(d)

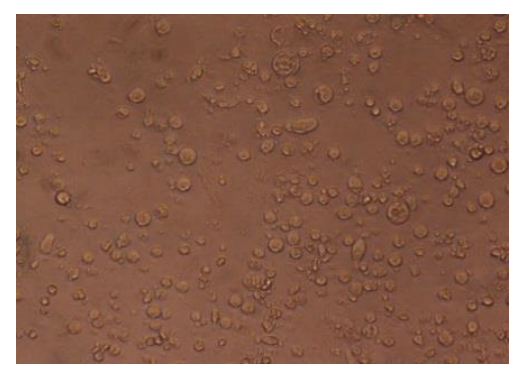

C3 $48 \mathrm{~h}$

(e)

FIGURE 5: Microscope images (20x) of K562 cells with controls $\left(\mathrm{H}_{2} \mathrm{O}\right.$ and DMSO) and $\mathrm{IC}_{50}$ values of metal complexes for 48 and 72 hours. (a) Image of K562 cells at $72 \mathrm{~h}$ with distilled water as a control; (b) and (c) images of the cells at $72 \mathrm{~h}$ with $\mathrm{IC}_{50}$ values of $\mathrm{C} 1$ and $\mathrm{C} 2 \mathrm{complexes}$, respectively; (d) image of the cells at $48 \mathrm{~h}$, incubated with DMSO as a control of C3 complex; (e) image of the cells at $48 \mathrm{~h}$, incubated with $\mathrm{IC}_{50}$ value of $\mathrm{C} 3$.

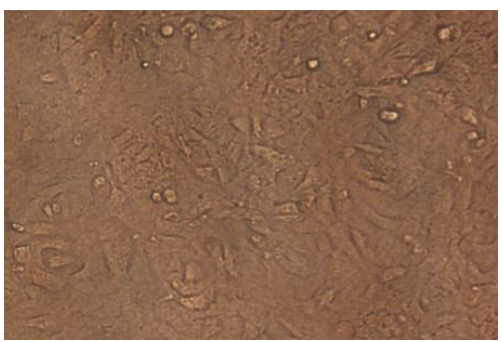

$\mathrm{H}_{2} \mathrm{O} 72 \mathrm{~h}$

(a)

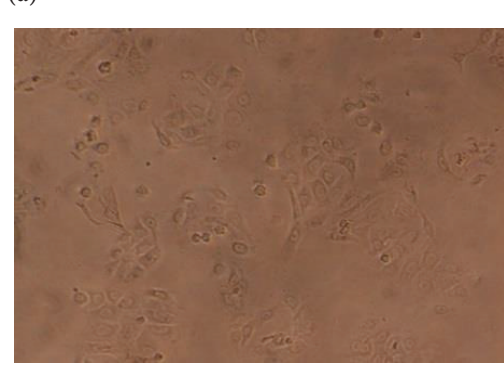

DMSO $48 \mathrm{~h}$

(d)

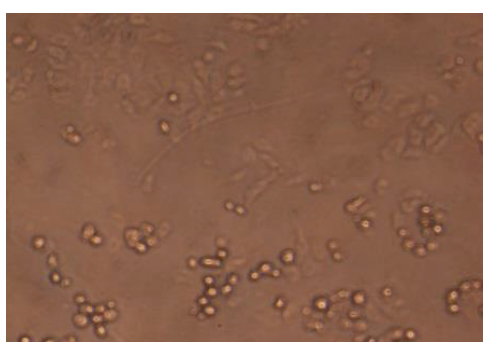

$\mathrm{C} 172 \mathrm{~h}$

(b)

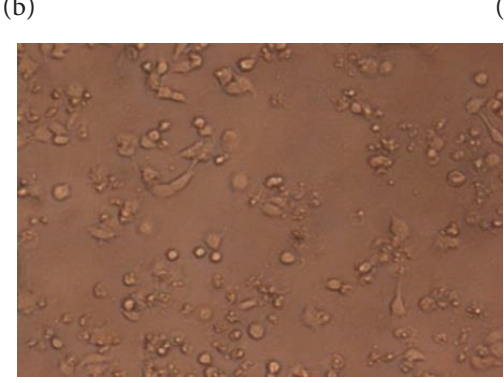

$\mathrm{C} 348 \mathrm{~h}$

(e)

Figure 6: Microscope images (20x) of A549 cells with controls $\left(\mathrm{H}_{2} \mathrm{O}\right.$ and DMSO) and $\mathrm{IC}_{50}$ values of metal complexes for 48 and 72 hours. (a) image of A549 cells at $72 \mathrm{~h}$ with distilled water as a control; (b) and (c) images of the cells at $72 \mathrm{~h}$ with $\mathrm{IC}_{50}$ values of $\mathrm{Cl}$ and $\mathrm{C} 2 \mathrm{complexes}$, respectively; (d) image of the cells at $48 \mathrm{~h}$, incubated with DMSO as a control of C3 complex; (e) image of the cells at $48 \mathrm{~h}$, incubated with $\mathrm{IC}_{50}$ value of $\mathrm{C} 3$. 


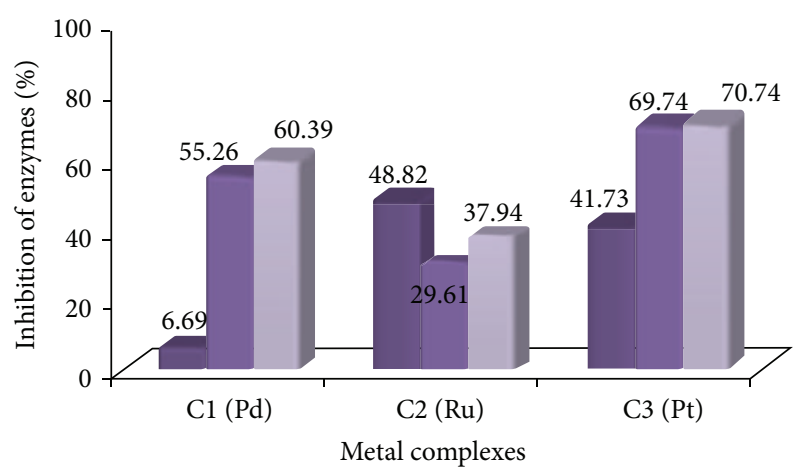

$$
\begin{aligned}
& \triangle \text { Cat } \\
& \triangle \mathrm{GPx} \\
& \text { TrxR }
\end{aligned}
$$

FIgURE 7: Percentages of inhibition of TrxR, GPx, and Cat enzymes of $\mathrm{A} 549$ cells in the given period, after incubation, with $\mathrm{IC}_{50}$ values of $\mathrm{C} 1, \mathrm{C} 2$, and $\mathrm{C} 3$ complexes.

The catalase activities of both types of cells were found to be at higher levels than those of the other two enzymes' activities. The catalase activity of healthy human cells is already higher than GPx and TrxR activity. The catalase-specific activities of the A549 and K562 control cells (untreated with any complex) were found to be $854.73 \mathrm{U} / \mathrm{mg}$ protein and $354.93 \mathrm{U} / \mathrm{mg}$ protein, respectively, and these activities were accepted as $100 \%$ activity. Some of the tested compounds showed good catalase inhibitor properties. After incubation of the A549 cells with $\mathrm{C} 1(4.625 \mathrm{mM}, 72 \mathrm{~h}), \mathrm{C} 2(7.436 \mathrm{mM}$, $72 \mathrm{~h}$ ), and C3 $(0.158 \mathrm{mM}, 48 \mathrm{~h})$, Cat was inhibited at $60.39 \%$, $37.94 \%$, and $70.47 \%$, respectively (Figure 7 ). Consequently, C3 was more effective at Cat inhibition in A549 cells than were $\mathrm{C} 1$ and C2. The same inhibition effect of C3 (69.34\%) was observed in $\mathrm{K} 562$ cells (Figure 8). While $\mathrm{Cl}$ inhibited the Cat of K562 cells (62.84\%) at almost the same level as it did the Cat of A549 cells, C2 inhibited the Cat of K562 cells (65.65\%) more than it did the Cat of A549 cells.

3.1.4. Statistical Comparison. The statistical findings of this study showed that while there was no significant difference between C2 and C3 in terms of TrxR inhibition, both differed significantly from the control in the A549 cell line. There was a remarkable difference in TrxR inhibition in the K562 cell line between all three complexes and the control group. Statistically, C1 inhibited the TrxR enzyme of K562 cells far more than C2 did but only slightly more than C3 did (Table 1).

There were significant differences between all three tested compounds and the control group in terms of GPx inhibition in the A549 cell line (Table 1). While the least difference was seen between $\mathrm{C} 2$ and the control, the greatest difference was between $\mathrm{C} 3$ and the control. The results showed no respectable differences among the three complexes when applied to K562 cells, but there was considerable difference between all three of them and the control group.

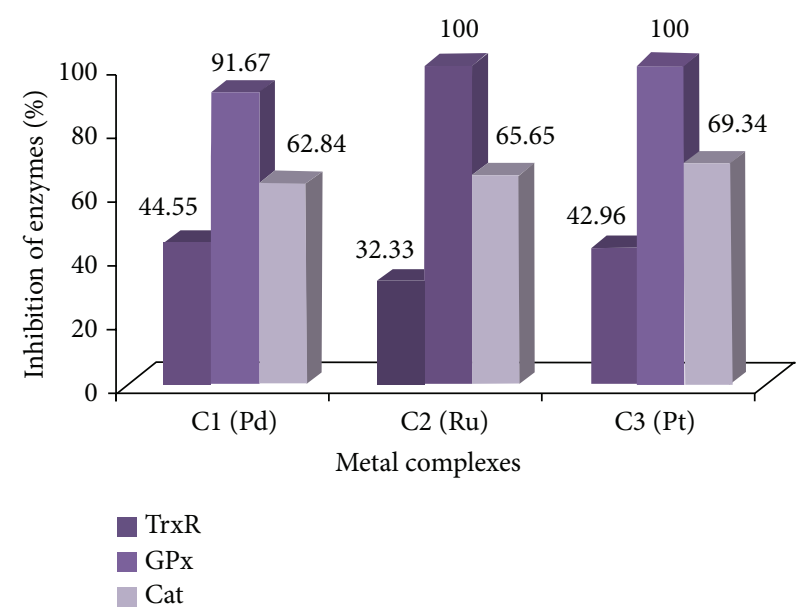

Figure 8: Percentages of inhibition of TrxR, GPx, and Cat enzymes of $\mathrm{K} 562$ cells in the given period, after incubation, with $\mathrm{IC}_{50}$ values of $\mathrm{C} 1, \mathrm{C} 2$, and $\mathrm{C} 3$ complexes.

The most significant differences of Cat inhibition in A549 cells were between $\mathrm{C} 3$ and the control group. The differences between $\mathrm{Cl}$ and the control were greater than those found between $\mathrm{C} 3$ and the control, while those between $\mathrm{C} 2$ and the control were the smallest. There was significant disparity between all three of the compounds tested and the control group with regard to Cat inhibition, with the greatest difference being between $\mathrm{C} 3$ and the control and the least between $\mathrm{C} 1$ and the control (Table 1).

3.2. Discussion. In this study, three original metal phosphine complexes were found to have variable cytotoxic activities at the mM level in A549 and K562 cells. In addition to the cytotoxic activities, measurement of the activities of the enzymes TrxR, GPx, and Cat was attempted by use of metal complexes as inhibitors in both cells. Phosphines are widely used as a ligand group in the treatment of cancer via the inhibition of antioxidant enzymes [4, 13, 35, 38]. Platinum complexes belong to a group of metal complexes with good TrxR-inhibiting properties $[5,19,36]$, but ruthenium complexes are new in this area, and they exhibit properties of good inhibitors of TrxR and of some other related enzymes [3,3840]. Palladium complexes are one of the least common metals to be used at the inhibition of these enzymes.

Since high levels of the enzyme TrxR in many human cancer cell lines prevent anticancer agents from inducing apoptosis [39], inactivation of the TrxR enzyme was investigated in this study. The inactivation of TrxR and of the closely related enzyme glutathione peroxidase was also examined. Although both of the enzymes belong to the TrxR system, metal complexes exhibit enzyme-selective or cell-selective inhibition according to the structure of the metal complex or ligand. It is already known that anticancer activity is closely connected to the chemical structure of the metal complexes [3], as the results of this study show. In some reported studies, phosphine-Au derivatives inhibited TrxR more than GR [41, 42]. For instance, the results of our study demonstrated 
that the TrxR inhibition effects of all three tested metal phosphine compounds were higher in A549 cells than their GPx inhibition effects. However, the same complexes showed less inhibition in K562 cells.

Most of the electrophilic compounds (like metal complexes) interact selectively and irreversibly with the $\mathrm{SH} / \mathrm{Se}$ group at the active site of the enzyme, thus becoming inhibitors of TrxR [43-45]. For example, in one reported study, the crystal structure of phosphole-gold(I) complexes showed a coordination bond between one phosphole-gold unit and the host enzyme. And the second gold atom formed a linear $\mathrm{S}-\mathrm{Au}-\mathrm{S}$ bond by losing its chloride atoms during interaction with the active site [39]. Selenolates are softer donor ligands compared to thiolates. So they behave better as substrates for some metal ions $[5,46]$. Moreover, other properties of ligands, such as size, charge, and lipophilicity, are important for biological activity.

A sequential thiol-exchange mechanism, in which thiolates act as soft ligands forming covalent bonds with the soft metal ions, is suggested to explain the reactivity and cellular distribution of the tested phosphine compounds which were used for inactivation of the TrxR and GPx enzymes in A549 and K562 cells. For instance, Becker at al. suggest that selenocysteine residue is a suitable site for platination in hTrxR and that the mechanism involves a selenolate-thiolate exchange with the ligand of the Pt(II) compounds. This inactivation via metal complexes may also cause an inhibition of DNA synthesis [18]. On the other hand, we estimate that because they act as inhibitors of TrxR and related enzymes (i.e., Cat and GPx), $\mathrm{Pd}(\mathrm{II}), \mathrm{Pt}(\mathrm{II})$, and $\mathrm{Ru}(\mathrm{II})$ phosphine complexes may also make a modification of the redox state of the cells. Thus, they cause an increased production of $\mathrm{H}_{2} \mathrm{O}_{2}$ and oxidation of the components of the enzyme system, therefore creating the conditions for cell death, as reported in some other studies [4, 47-49]. And it is known that a significant increase in the intracellular $\mathrm{H}_{2} \mathrm{O}_{2}$ production causes apoptotic cell death in tumor cells [50]. There is much experimental evidence that cancer cells are more susceptible to $\mathrm{H}_{2} \mathrm{O}_{2}$-induced cell death than normal cells [51, 52]. Increasing the cellular levels of $\mathrm{H}_{2} \mathrm{O}_{2}$ by using $\mathrm{H}_{2} \mathrm{O}_{2}$ generating systems instead of direct application of $\mathrm{H}_{2} \mathrm{O}_{2}$ may be one of the most efficient ways to kill cancer cells [53].

\section{Conclusion}

Our studies have contributed to understanding of metal phosphines' new role in cancer cells. The results have indicated that tested metal phosphine compounds were effectivein terms of cell death on K562 and A549 cell lines in vitro. Consequently, the $\mathrm{Pd}, \mathrm{Ru}$, and $\mathrm{Pt}$ complexes of phosphines are potentially novel therapeutic agents for K562 and A549 carcinoma cells. It should be noted that the molecular structures of the compounds subscribe to their cytotoxic and mentioned enzyme inhibitor effects.

\section{Conflict of Interests}

The authors declare that there is no conflict of interests regarding the publication of this paper.

\section{Acknowledgments}

The authors are grateful to pediatric immunology Professor Dr. Mustafa Yilmaz for sharing his academic experiences. In addition, the authors are thankful to Çukurova University's Hematology Laboratory for allowing them to use their facilities and Gaziantep University's Cell Laboratory for providing cell lines.

\section{References}

[1] W. Zhong, T. Yan, R. Lim, and L. W. Oberley, "Expression of superoxide dismutases, catalase, and glutathione peroxidase in glioma cells," Free Radical Biology and Medicine, vol. 27, no. 1112, pp. 1334-1345, 1999.

[2] D. Deeb, X. Gao, H. Jiang et al., "Oleanane triterpenoid CDDOMe inhibits growth and induces apoptosis in prostate cancer cells through a ROS-dependent mechanism," Biochemical Pharmacology, vol. 79, no. 3, pp. 350-360, 2010.

[3] X. Yang, L. Chen, Y. Liu et al., "Ruthenium methylimidazole complexes induced apoptosis in lung cancer A549 cells through intrinsic mitochondrial pathway," Biochimie, vol. 94, no. 2, pp. 345-353, 2012.

[4] V. Gandin, A. P. Fernandes, M. P. Rigobello et al., "Cancer cell death induced by phosphine gold(I) compounds targeting thioredoxin reductase," Biochemical Pharmacology, vol. 79, no. 2, pp. 90-101, 2010.

[5] S. Urig and K. Becker, "On the potential of thioredoxin reductase inhibitors for cancer therapy," Seminars in Cancer Biology, vol. 16, no. 6, pp. 452-465, 2006.

[6] O. Zava, S. M. Zakeeruddin, C. Danelon, H. Vogel, M. Grätzel, and P. J. Dyson, "A cytotoxic ruthenium tris(Bipyridyl) complex that accumulates at plasma membranes," ChemBioChem, vol. 10, no. 11, pp. 1796-1800, 2009.

[7] F. Linares, M. A. Galindo, S. Galli, M. A. Romero, J. A. R. Navarro, and E. Barea, "Tetranuclear coordination assemblies based on half-sandwich ruthenium(II) complexes: noncovalent binding to DNA and cytotoxicity," Inorganic Chemistry, vol. 48, no. 15, pp. 7413-7420, 2009.

[8] S. H. van Rijt, A. J. Hebden, T. Amaresekera et al., "Amide linkage isomerism as an activity switch for organometallic osmium and ruthenium anticancer complexes," Journal of Medicinal Chemistry, vol. 52, no. 23, pp. 7753-7764, 2009.

[9] X. Meng, M. L. Leyva, M. Jenny et al., "A ruthenium-containing organometallic compound reduces tumor growth through induction of the endoplasmic reticulum stress gene CHOP," Cancer Research, vol. 69, no. 13, pp. 5458-5466, 2009.

[10] E. Meggers, G. E. Atilla-Gokcumen, K. Gründler, C. Frias, and A. Prokop, "Inert ruthenium half-sandwich complexes with anticancer activity," Dalton Transactions, no. 48, pp. 1088210888, 2009.

[11] N. Farrell, Y. Qu, U. Bierbach, M. Valsecchi, and E. Menta, Cis-Platin: Chemistry and Biochemistry of a Leading Anticancer Drug, Wiley, Weinheim, Germany, 1999.

[12] C. K. Mirabelli, R. K. Johnson, C. M. Sung, L. Faucette, K. Muirhead, and S. T. Crooke, "Evaluation of the in vivo antitumor activity and in vitro cytotoxic properties of auranofin, a coordinated gold compound, in murine tumor models," Cancer Research, vol. 45, no. 1, pp. 32-39, 1985.

[13] C. Santini, M. Pellei, G. Papini et al., "In vitro antitumour activity of water soluble $\mathrm{Cu}(\mathrm{I}), \mathrm{Ag}(\mathrm{I})$ and $\mathrm{Au}(\mathrm{I})$ complexes 
supported by hydrophilic alkyl phosphine ligands," Journal of Inorganic Biochemistry, vol. 105, no. 2, pp. 232-240, 2011.

[14] N. Manav, A. K. Mishra, and N. K. Kaushik, “Triphenyl phosphine adducts of platinum(IV) and palladium(II) dithiocarbamates complexes: a spectral and in vitro study," Spectrochimica Acta-Part A: Molecular and Biomolecular Spectroscopy, vol. 60, no. 13, pp. 3087-3092, 2004.

[15] C. Wetzel, P. C. Kunz, M. U. Kassack et al., "Gold(I) complexes of water-soluble diphos-type ligands: synthesis, anticancer activity, apoptosis and thioredoxin reductase inhibition," Dalton Transactions, vol. 40, no. 36, pp. 9212-9220, 2011.

[16] O. Rackham, S. J. Nichols, P. J. Leedman, S. J. Berners-Price, and A. Filipovska, "A gold(I) phosphine complex selectively induces apoptosis in breast cancer cells: implications for anticancer therapeutics targeted to mitochondria," Biochemical Pharmacology, vol. 74, no. 7, pp. 992-1002, 2007.

[17] F. Zhao, J. Yan, S. Deng et al., "A thioredoxin reductase inhibitor induces growth inhibition and apoptosis in five cultured human carcinoma cell lines," Cancer Letters, vol. 236, no. 1, pp. 46-53, 2006.

[18] D. Mustacich and G. Powis, “Thioredoxin reductase," Biochemical Journal, vol. 346, no. 1, pp. 1-8, 2000.

[19] K. Becker, C. Herold-Mende, J. J. Park, G. Lowe, and R. Heiner Schirmer, "Human thioredoxin reductase is efficiently inhibited by (2,2l:6l,2l-terpyridine)platinum(II) complexes. Possible implications for a novel antitumor strategy," Journal of Medicinal Chemistry, vol. 44, no. 17, pp. 2784-2792, 2001.

[20] L. Zhong and A. Holmgren, "Essential role of selenium in the catalytic activities of mammalian thioredoxin reductase revealed by characterization of recombinant enzymes with selenocysteine mutations," Journal of Biological Chemistry, vol. 275, no. 24, pp. 18121-18128, 2000.

[21] S. Gromer, J. Wissing, D. Behne et al., "A hypothesis on the catalytic mechanism of the selenoenzyme thioredoxin reductase," Biochemical Journal, vol. 332, part 2, pp. 591-592, 1998.

[22] C. H. Williams Jr., L. David Arscott, S. Müller et al., “Thioredoxin reductase: two modes of catalysis have evolved," European Journal of Biochemistry, vol. 267, no. 20, pp. 6110-6117, 2000.

[23] P. M. Scarbrough, K. A. Mapuskar, D. M. Mattson, D. Gius, W. H. Watson, and D. R. Spitz, "Simultaneous inhibition of glutathione- and thioredoxin-dependent metabolism is necessary to potentiate 17AAG-induced cancer cell killing via oxidative stress," Free Radical Biology and Medicine, vol. 52, no. 2, pp. 436-443, 2012.

[24] C. D. Putnam, A. S. Arvai, Y. Bourne, and J. A. Tainer, "Active and inhibited human catalase structures: ligand and NADPH binding and catalytic mechanism," Journal of Molecular Biology, vol. 296, no. 1, pp. 295-309, 2000.

[25] T. Keleş, "Synthesis of new water soluble aminomethylphosphine and their metal complexes and investigation of their biological activity," Department of Chemistry Institue of Natural and Applied Sciences University of Çukurova, ADANA, 2013.

[26] B. Akkuş, Synthesis of Transitıon Metal Complexes with Mixed Ligands and Characterization, Department of Chemistry, Institue of Natural and Applied Sciences, University of Çukurova, Adana, Turkey, 2009.

[27] S. Tardito, C. Isella, E. Medico et al., "The thioxotriazole copper (II) complex A0 induces endoplasmic reticulum stress and paraptotic death in human cancer cells," Journal of Biological Chemistry, vol. 284, no. 36, pp. 24306-24319, 2009.
[28] A. Claiborne, "Catalase activity," in Handbook of Methods for Oxygen Radical Research, R. A. Greenwald, Ed., pp. 283-284, CRC Press, Boca Raton, Fla, USA, 1985.

[29] O. H. Lowry, N. J. Rosebrough, A. L. Farr, and R. J. Rondall, "Protein measurement with the Folin phenol reagent," The Journal of Biological Chemistry, vol. 193, no. 1, pp. 265-275, 1951.

[30] E. Beutler and E. Beutler, "Red cell metabolism," in A Manual of Biochemical Methods, pp. 66-68, Grone \& Stratton, New York, NY, USA, 1971.

[31] S. Gromer, L. D. Arscott, C. H. Williams Jr., R. H. Schirmeri, and K. Becker, "Human placenta thioredoxin reductase. Isolation of the selenoenzyme, steady state kinetics, and inhibition by therapeutic gold compounds," The Journal of Biological Chemistry, vol. 273, no. 32, pp. 20096-20101, 1998.

[32] D. G. Kleinbaum, L. L. Kupper, K. E. Muller, and A. Nizan, Applied Regression Analysis and Other Multivariate Methods, Duxbury Press, Boston, Mass, USA, 1998.

[33] P. E. Garrou, " $\Delta_{R}$ ring contributions to 31P NMR parameters of transition-metal-phosphorus chelate complexes," Chemical Reviews, vol. 81, no. 3, pp. 229-266, 1981.

[34] F. R. Pavan, G. V. Poelhsitz, M. I. F. Barbosa et al., "Ruthenium(II) phosphine/diimine/picolinate complexes: inorganic compounds as agents against tuberculosis," European Journal of Medicinal Chemistry, vol. 46, no. 10, pp. 5099-5107, 2011.

[35] G. Lupidi, L. Avenali, M. Bramucci et al., "Synthesis, properties, and antitumor effects of a new mixed phosphine gold(I) compound in human colon cancer cells," Journal of Inorganic Biochemistry, vol. 124, pp. 78-87, 2013.

[36] P. Mura, M. Camalli, A. Bindoli et al., "Activity of rat cytosolic thioredoxin reductase is strongly decreased by trans-[bis (2amino-5-methylthiazole)tetrachlororuthenate(III)]: first report of relevant thioredoxin reductase inhibition for a ruthenium compound," Journal of Medicinal Chemistry, vol. 50, no. 24, pp. 5871-5874, 2007.

[37] A.-B. Witte, K. Anestål, E. Jerremalm, H. Ehrsson, and E. S. J. Arnér, "Inhibition of thioredoxin reductase but not of glutathione reductase by the major classes of alkylating and platinum-containing anticancer compounds," Free Radical Biology \& Medicine, vol. 39, no. 5, pp. 696-703, 2005.

[38] A. K. Renfrew, A. E. Egger, R. Scopelliti, C. G. Hartınger, and P. J. Dyson, "Synthesis and characterisation of the water soluble bis -phosphine complex $\left[\mathrm{Ru}\left(\eta^{6}\right.\right.$-cymene $)\left(\mathrm{PPh}_{2}\left(\mathrm{o}-\mathrm{C}_{6} \mathrm{H}_{4} \mathrm{O}\right)\right.$ $\left.k^{2}-P, O\right)($ pta $\left.)\right]^{+}$and an investigation of its cytotoxic effects," Comptes Rendus Chimie, vol. 13, no. 8-9, pp. 1144-1150, 2010.

[39] P. C. A. Bruijnincx and P. J. Sadler, "New trends for metal complexes with anticancer activity," Current Opinion in Chemical Biology, vol. 12, no. 2, pp. 197-206, 2008.

[40] S. M. Guichard, R. Else, E. Reid et al., "Anti-tumour activity in non-small cell lung cancer models and toxicity profiles for novel ruthenium(II) based organo-metallic compounds," Biochemical Pharmacology, vol. 71, no. 4, pp. 408-415, 2006.

[41] S. Gromer, L. D. Arscott, C. H. Williams Jr., R. H. Schirmeri, and K. Becker, "Human placenta thioredoxin reductase," The Journal of Biological Chemistry, vol. 273, no. 32, pp. 20096-20101, 1998.

[42] E. Vergara, A. Casini, F. Sorrentino et al., "Anticancer therapeutics that target selenoenzymes: synthesis, characterization, in vitro cytotoxicity, and thioredoxin reductase inhibition of a series of gold(I) complexes containing hydrophilic phosphine ligands," ChemMedChem, vol. 5, no. 1, pp. 96-102, 2010.

[43] K. Becker, S. Gromer, R. H. Schirmer, and S. Müller, "Thioredoxin reductase as a pathophysiological factor and drug target," 
European Journal of Biochemistry, vol. 267, no. 20, pp. 6118-6125, 2000.

[44] Y. Nishinaka, H. Nakamura, H. Masutani, and J. Yodoi, "Redox control of cellular function by thioredoxin; a new therapeutic direction in host defence," Archivum Immunologiae et Therapiae Experimentalis, vol. 49, no. 4, pp. 285-292, 2001.

[45] J. Nordberg and E. S. J. Arnér, "Reactive oxygen species, antioxidants, and the mammalian thioredoxin system," Free Radical Biology \& Medicine, vol. 31, no. 11, pp. 1287-1312, 2001.

[46] R. G. Pearson, “Acids and bases," Science, vol. 151, no. 3707, pp. $172-177,1966$.

[47] A. Cingolani, J. V. Hanna, M. Pellei et al., "Crystal structures and vibrational and solution and solid-state (CPMAS) NMR spectroscopic studies in triphenyl phosphine, arsine, and stibine silver(I) bromate systems, $\left(\mathrm{R}_{3} \mathrm{E}\right) \mathrm{xAgBrO}_{3}(\mathrm{E}=\mathrm{P}, \mathrm{As}, \mathrm{Sb} ; x=$ 1-4)," Inorganic Chemistry, vol. 42, no. 16, pp. 4938-4948, 2003.

[48] K. G. Daniel, P. Gupta, R. H. Harbach, W. C. Guida, and Q. P. Dou, "Organic copper complexes as a new class of proteasome inhibitors and apoptosis inducers in human cancer cells," Biochemical Pharmacology, vol. 67, no. 6, pp. 1139-1151, 2004.

[49] C. Marzano, V. Gandin, A. Folda, G. Scutari, A. Bindoli, and M. P. Rigobello, "Inhibition of thioredoxin reductase by auranofin induces apoptosis in cisplatin-resistant human ovarian cancer cells," Free Radical Biology \& Medicine, vol. 42, no. 6, pp. 872881, 2007.

[50] J. L. Hirpara, M.-V. Clément, and S. Pervaiz, "Intracellular acidification triggered by mitochondrial-derived hydrogen peroxide is an effector mechanism for drug-induced apoptosis in tumor cells," Journal of Biological Chemistry, vol. 276, no. 1, pp. 514-521, 2001.

[51] Q. Chen, M. G. Espey, M. C. Krishna et al., "Pharamacologic ascorbic acid concentrations selectively kill cancer cells: action as a pro-drug to deliver hydrogen peroxide to tissuse," Proceedings of the National Academy of Sciences of the United States of America, vol. 102, no. 38, pp. 13604-13609, 2005.

[52] A. M. Evens, P. Lecane, D. Magda et al., "Motexafin gadolinium generates reactive oxygen species and induces apoptosis in sensitive and highly resistant multiple myeloma cells," Blood, vol. 105, no. 3, pp. 1265-1273, 2005.

[53] M. López-Lázaro, "Dual role of hydrogen peroxide in cancer: possible relevance to cancer chemoprevention and therapy," Cancer Letters, vol. 252, no. 1, pp. 1-8, 2007. 

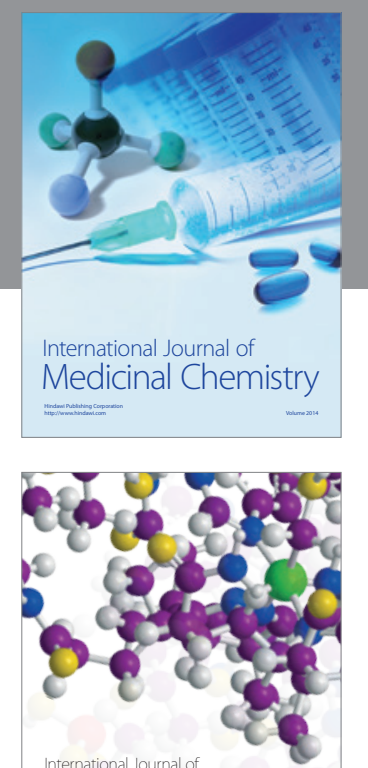

\section{Carbohydrate} Chemistry

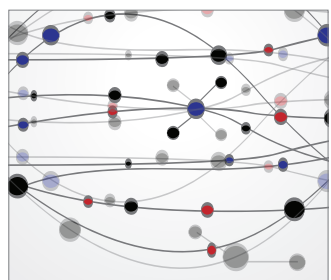

The Scientific World Journal
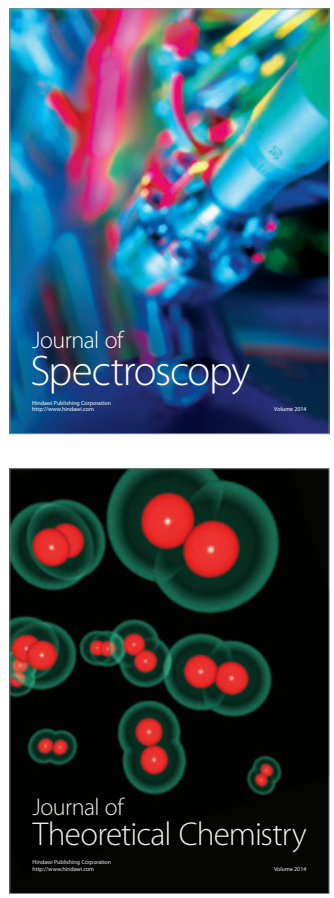
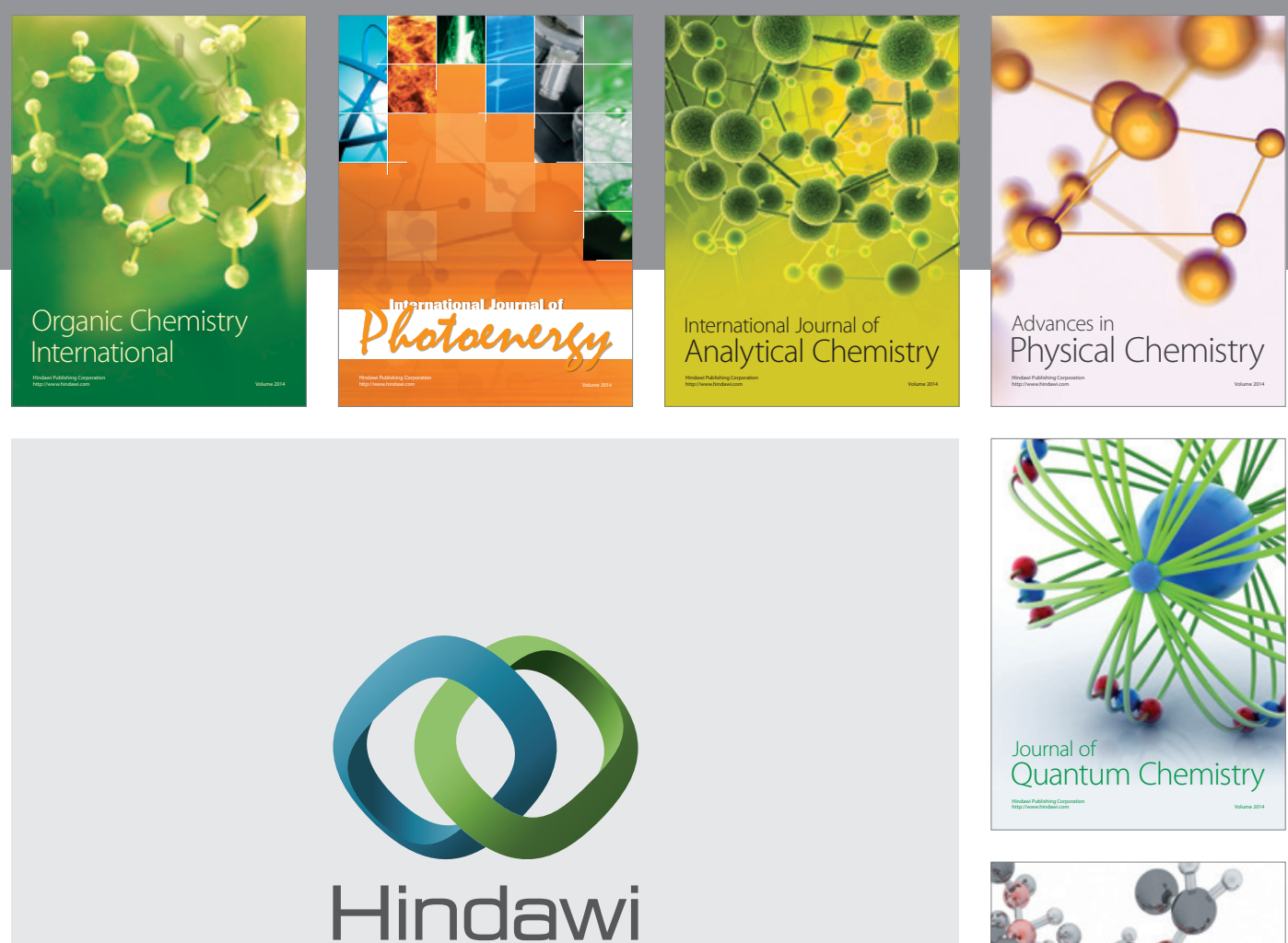

Submit your manuscripts at

http://www.hindawi.com

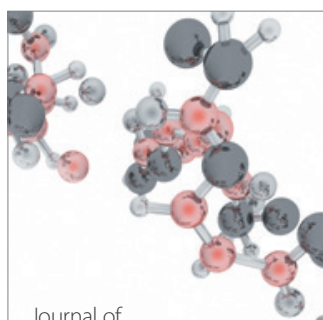

Analytical Methods

in Chemistry

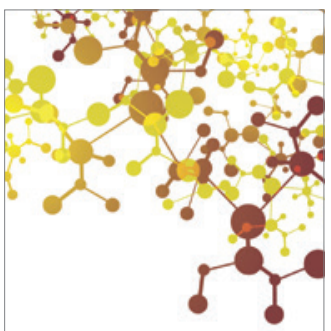

Journal of

Applied Chemistry

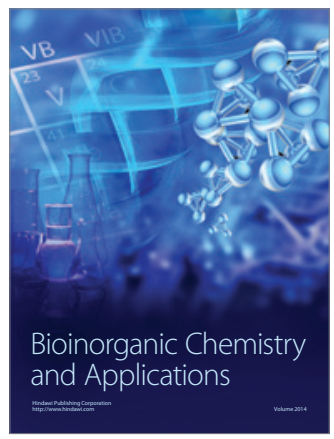

Inorganic Chemistry
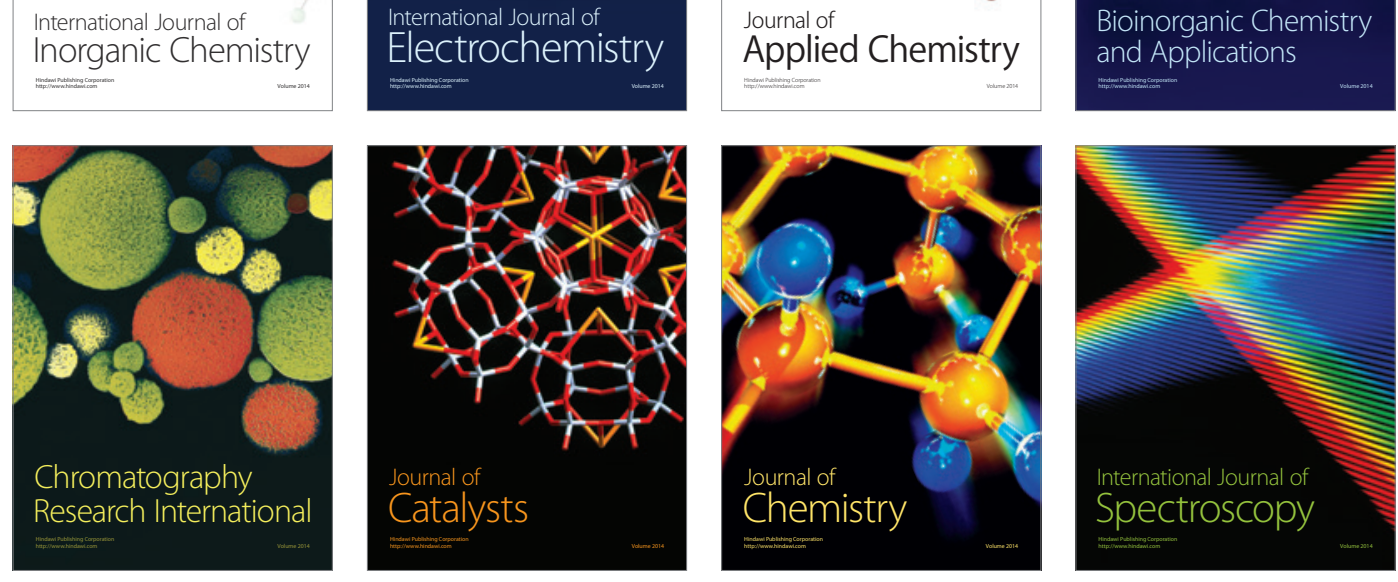